\title{
The use of social media for engineering lecturers and students
}

\author{
Achmad Shobirin ${ }^{1, *}$, Dian Candra Lestari ${ }^{2}$, Firdausi Nuzula ${ }^{3}$, Fitri Umeidah ${ }^{4}$ \\ Department of Electrical Engineering, State University of Malang, Malang, Indonesia \\ ${ }^{1}$ neraka.malam@outlook.com*; ${ }^{2}$ dnivers@ gmail.com, ${ }^{3}$ ChagyUsi@gmail.com, ${ }^{4}$ fitriumeidah@ gmail.com \\ * corresponding author
}

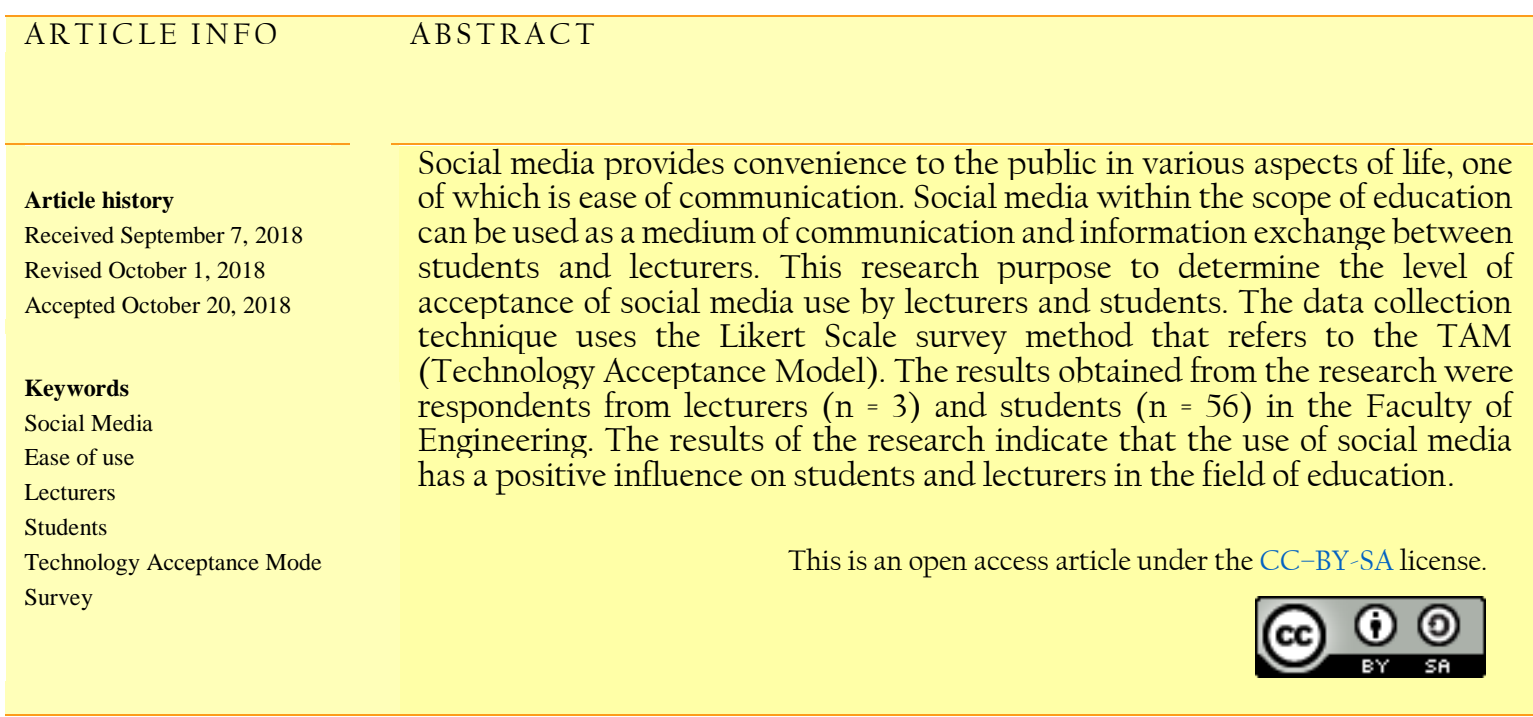

\section{Introduction}

Social media are an internet-based communication media that can be accessed by anyone and anywhere. Social media can take on various forms, such as forums, social networks, wikis, and microblogging [1]. Information shared through social media can be a message in the form of text, images, audio, and even video [2]. nowadays, social media is not only a medium for communication, but also as an e-learning media, politics, and e-commerce [3].

Referring to data from "We Are Social", indicate that the average internet usage every day reaches 6 hours per active user with the number reaching 4 billion worldwide in 2018. In addition, the same report shows Indonesia ranks third under India and China with around 24 million users [4]. With a large number of users, social media has an important role in daily life, both from a social aspect, educational, economic, political and health. Therefore, this research purpose to observe the influence of social media in education, especially for students and lecturers at the Faculty of Engineering. [5].

Observations made in this research using a questionnaire model that refers to TAM (Technology Acceptance Model). TAM is a model that is used to analyze the factors that influence the receipt of an information system. According to previous research, it was mentioned that users tend to use the system if the system is easy to use and useful. TAM explains and estimates user acceptance of a technology based on certain factors [6]. The questionnaire uses a Likert scale where the subjects are lecturers and students.

Based on research previously conducted by Mikako Ogawa and his friends entitled "Social media use at work: comparison of the United States and Japan" states that social media in Japan and America was used for product advertising (79\%), research (55\%), sales (46\%), recruitment (38\%), developing community (32\%) and improving customer service (33\%). So, this research will discuss the influence of ease of use and usefulness of social media during the teaching and learning process between lecturers and students, such as the use of social media in sharing information and facilitating students' understanding in learning [7]. 


\section{Method}

The benefits provided by social media in supporting the work of lecturers and students in the teaching and learning process, sharing information about education can be known by using a questionnaire with research questions that refer to the TAM research model (Technology Acceptance Model). TAM is useful for knowing attitudes towards the presence of a technology [8]. TAM is one type of theory that utilizes behavioral theory approaches (Behavior Theory), the theory is used to conduct an assessment of information technology adoption processes. The TAM theory focuses on the perception of ease in use and the benefits possessed by an information system so that users have an interest in using the information system [9].

Based on various studies on TAM, it was stated that experience is an important predictor in knowing ease and usefulness, therefore it does not rule out the possibility that the perception or experience of social media in general can have an impact on the use of social media in the work environment. Figure 1 shows the research model based on the reference journal and the questions used in the research. Questions are addressed to 2 types of respondents, namely lecturers and students, who have different questions between the two.

The first question for lecturers is, Can social media like YouTube make it easier to find reference material for teaching materials? And the second question for lecturers: Is social media like Instagram easier for you to share information about meetings and other important activities?

Moreover, the first question for students: Did you use social media chat like WhatsApp for college needs? And the second question for students: Can social media like Facebook help in supporting lecture activities?

\section{General SM}

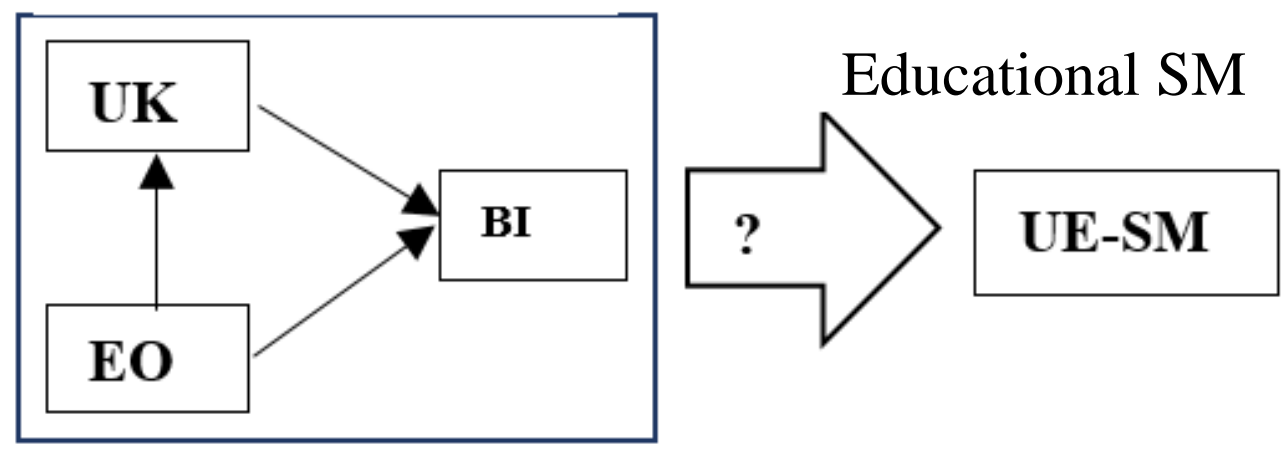

Fig. 1.The research model for the experience of using social media in general.

Previous research used the monkey survey method to find out the reasons and goals of using social media in work between the United States and Japan using the TAM research model [10]. The research "The Use of Social Media for Lecturers and Engineering Students" developed from previous research conducted by Mikako Ogawa and his friends, entitled "Social Media Use at Work: a comparison of the United States and Japan" where in this research using a questionnaire developed using Google Form with 5 general questions and 10 specific statements on each type of respondent, namely students and lecturers.

Some questions consist of the sections shown in Table 2. The survey was conducted at Faculty of Engineering, Universitas Negeri Malang. The survey was conducted from October 2, 2018, to October 10, 2018, and already had 3 respondents from Lecturers and 56 respondents from students with details: Electrical Engineering Lecturer $=2$, Electrical Engineering students $=26$, Industrial Technology students $=10$, Mechanical Engineering students $=14$, and Civil Engineering students $=6$. With this survey, we can find out the role of social media for Education and the use of social media for Education. 
Table 1.

Description of Variables

\begin{tabular}{cccc}
\hline Variables & Description & Scope & Questions \\
\hline EOU & Ease of use & General-SM & 4 \\
\hline UK & $\begin{array}{c}\text { Usefulness of collective } \\
\text { knowledge }\end{array}$ & General-SM & 3 \\
\hline BI & Behavior intention & General-SM & 5 \\
\hline UE-SM & Usefulness for Education & Education-SM & 3
\end{tabular}

\section{Results and Discussion}

We use social media as the purpose of used for student and lecturer respondents in the scope of the UM Faculty of Engineering. The results we obtained from the weighting of the mean variables that make sense using social media describe the results. The variety of questions found from the variables that are present with the number of questions calculated. The EOU variable results of $26.7 \%$, UK by $20 \%$, BI by $33 \%$, and EU-SM by $20 \%$ from $100 \%$ percentage.

This study analyzes variables related to social media between lecturers and students. Thus, finding a significant use of social media to improve education effectiveness [11].

Table 2. Categories of Social Media Functions

\begin{tabular}{ccccc}
\hline $\begin{array}{c}\text { Functions of } \\
\text { Social Media }\end{array}$ & $\begin{array}{c}\text { Strongly } \\
\text { Agree }\end{array}$ & Agree & $\begin{array}{c}\text { Slightly } \\
\text { Agree }\end{array}$ & Disagree \\
\hline Sharing & 45.8 & 32.1 & 45.8 & 13 \\
\hline Communication & 42.9 & 53.6 & 1.75 & 1.75 \\
\hline Productive & 23.6 & 48 & 17.85 & 2.2 \\
\hline Education Facility & 11.6 & 46.8 & 16.5 & 25.1 \\
\hline Meeting of Online & 8.95 & 42.85 & 33.9 & 5.35 \\
\hline
\end{tabular}

The functions of social media based on categories are divided into 5 types like sharing, communication, productive, educational facilities and online meetings. The several categories, it is known that the function of social media as a tool for sharing is the first choice with a score of 45.8 for respondents who "strongly agree".

Table 3. Types of Social Media

\begin{tabular}{ccccc}
\hline $\begin{array}{c}\text { Kinds of Social } \\
\text { Media }\end{array}$ & $\begin{array}{c}\text { Strongly } \\
\text { Agree }\end{array}$ & Agree & $\begin{array}{c}\text { Slightly } \\
\text { Agree }\end{array}$ & Disagree \\
\hline Facebook & 20.5 & 43.75 & 30 & 5.75 \\
\hline Instagram & 9.85 & 32.15 & 39.25 & 18.75 \\
\hline Whatsapp & 24.43 & 56.57 & 18 & 10 \\
\hline Youtube & 16.63 & 39.3 & 34.53 & 9.5 \\
\hline
\end{tabular}

Meanwhile, there are 4 types of social media that we apply to this study. Like as, Facebook, Instagram, WhatsApp, and YouTube. Based on Table 3, respondents were very excited about WhatsApp social media. It is proven by WhatsApp's score is 56,57 in the " strongly agree" column [12].

Table 4. The Purpose of Using Social Media

\begin{tabular}{ccccc}
\hline $\begin{array}{c}\text { The Purpose of } \\
\text { Use }\end{array}$ & $\begin{array}{c}\text { Strongly } \\
\text { Agree }\end{array}$ & Agree & $\begin{array}{c}\text { Slightly } \\
\text { Agree }\end{array}$ & Disagree \\
\hline Information & 15.1 & 41.4 & 23.9 & 10.1 \\
\hline Tutorial & 12.5 & 41.1 & 38.4 & 8 \\
\hline Reference & 24.1 & 49.1 & 16.5 & 4.45 \\
\hline
\end{tabular}


Then, the purpose of using social media is grouped into 3 parts, for information, learning media, and references. Three objectives, respondents stated that social media is quite good as a learning media shown in Table 4.

YouTube social media has a significant positive impact on education. Among students, YouTube can help in learning things and adding knowledge (tutorial). Whereas among lecturers, youtube helps in providing reference sources for teaching materials [13]. So, there is continuity between the use of youtube social media by students and lecturers. The lecturers provide material obtained from youtube reference sources. Then, students can implement it by looking at the tutorial on YouTube.

The use of social media to students boils down to knowledge and information. Where, when looking at a glimpse of information on Instagram social media or Facebook [14]. So, they will look for that information further on youtube social media because the information displayed in it is in the form of videos, images, sounds, and texts that are more accurate if only compared to information in the form of text/images/sounds only. Whereas, for social media types of chatting like Whatsapp are used as a medium of communication in relationships between students and lecturers.

The use of social media to lecturers is in accordance with the level of lecturers' needs when they are active in lectures. YouTube media can be used for teaching media, while chat media such as Whatsapp for discussion media as teaching materials about the field of education or supporting knowledge in academic matters both for personal chat and groups so that communication supports lecture activities.

When the lecture hours take place, lecturers can access social media as teaching materials which later can be studied and listened to by students. However, students are not permitted to access social media if there is no connection and guidance with the lecture hours that were taken at that time. So, when the lecture hours take place, lecturers have the authority to access social media while students do not have it.

Social media active users are respondents from the whole survey, $50 \%$ of respondents use social media for more than 5 years. Home and boarding are the places most often used to access social media, either by using Wi-Fi or cellular data packages. However, internet access using cellular data packages is often used by users because of its practical advantages. In using social media, the time needed is less than 1 hour. However, intensive (periodic) intervals of several minutes/hour if totaled in a day will take more than 1 hour.

Some respondents said that youtube social media has a greater influence on the field of education, especially in finding information/knowledge and references/material other than Instagram and Facebook [15]. Whereas, Whatsapp social media is limited as an interactive communication medium between students and lecturers.

The difference in this study leads to UK variables (Usefulness of Collective Knowledge) that are insightful uses as the main problem. The reasons for using social media, social media types, social media types, and social media goals can affect insightful uses. We must analyze each variable to obtain what variables are most influential in the use of social media in the education field based on user status. These variables are for reference in analyzing the questions that will be used in the questionnaire.

One limitation of this study is about samples. Where the sample needed for lecturer respondents is not enough as an analysis material in comparing the use of social media between lecturers and students. The samples for each department are also not balanced enough. So, we need additional studies regarding lecturer respondents to the use of social media and the widespread use of social media in each department. The target of lecturer respondents is 7 people for engineering faculty lecturers, while as many as 70 students for engineering faculty students. Respondents who were obtained did not reach the normal target, the lecturer with a percentage of $37.5 \%$ as many as 3 people and students with a percentage of $70 \%$ as many as 56 people. Lecturer respondents are difficult to obtain because they lack participation when filling out questionnaires assuming a large number of questions. 


\section{Conclusion}

Based on the results of research on the use of social media in the workplace with the proposed title "The Use of Social Media for Technical and Student Lecturers" research has been conducted for approximately 3 weeks with coverage from the Faculty of Engineering, Universitas Negeri Malang and the limitations of social media in using Whatsapp, Instagram, Youtube and Facebook in the field of education, the results of respondents for lecturers were 3 people and as many as 56 students in the Faculty of Engineering, Universitas Negeri Malang.

The use of social media on average tends to influence the usefulness of insight in accordance with the scope of the campus, for lecturers tend to discussion and communication media as teaching materials in lectures compared to students tend to media information sources, communication in lectures, and exploration media to develop creativity.

The ease of use of social media tends to be on social media as much as $50 \%$ of respondents with a usage period of more than 5 years, and frequent usage locations at home or dormitory using wi-fi or cellular data packages, regularly per minute/hour in one day spend more than 1 hour.

Social media has a different way of using respondents in the field of work in education in terms of information that is more likely to be youtube media than Facebook and Instagram, compared to Whatsapp which is more likely to be an interactive communication medium between lecturers and students so that the ease of using social media is based on the use of reason, the type of media, the type of media and the purpose of social media can improve the quality of teaching and learning during college.

\section{References}

[1] E. W. Ngai, K. L. K. Moon, S. S. Lam, E. S. Chin, and S. S. Tao, "Social media models, technologies, and applications: an academic review and case study," Ind. Manag. Data Syst., vol. 115, no. 5, pp. 769-802, 2015.

[2] Y. A. Ahmed, M. N. Ahmad, N. Ahmad, and N. H. Zakaria, "Social Media for Knowledge-Sharing: A Systematic Literature Review," Telemat. Informatics, 2018.

[3] W. M. Al-rahmi and A. M. Zeki, "A model of using social media for collaborative learning to enhance learners ' performance on learning," J. King Saud Univ. - Comput. Inf. Sci., vol. 29, no. 4, pp. 526-535, 2017.

[4] S. Kemp, "Digital in 2018: World's Internet Users the 4 Billion Mark," We Are Social: Special Report, 2018. [Online]. Available: https://wearesocial.com/blog/2018/01/global-digital-report-2018. [Accessed: 14-Jun-2018].

[5] C. I. Maican, A. M. Cazan, and R. C. Lixandroiu, "A Study on Academic Staff Personality and Technology Acceptance: The Case of Communication and Collaboration Applications," Comput. Educ., vol. 128, pp. 113-131, 2018.

[6] C. Yoon, "Extending the TAM for Green IT : A Normative Perspective," Comput. Human Behav., vol. 83, pp. 129-139, 2018.

[7] L. M. Kruse, D. R. Norris, and J. R. Flinchum, "Social Media as a Public Sphere? Politics on Social Media," Sociol. Q., vol. 59, no. 1, pp. 62-84, 2018.

[8] E. Fatmawati, “Technology Acceptance Model (TAM) Untuk Menganalisis Penerimaan Terhadap Sistem Informasi Perpustakaan," IQRA' J. Perpust. dan Inf., vol. 9, no. 1, 2015.

[9] S. T. Muntianah, E. S. Astuti, and D. F. Azizah, "Pengaruh Minat Perilaku Terhadap Actual Use Teknologi Informasi dengan Pendekatan Technology Acceptance Model (TAM)(Studi Kasus Pada Kegiatan Belajar Mahasiswa Fakultas Ilmu Administrasi Universitas Brawijaya Malang)," PROFIT (JURNAL Adm. BISNIS), vol. 6, no. 1, 2012.

[10] M. Ogawa, D. L. Amoroso, T. Mukahi, M. Tanabu, and O. Sato, "Social Media Use at Work : Comparison of the United States and Japan," in Annual Conference of Japan Society for Management Information, 2012, pp. 17-20. 
[11]K. Lim, C. Kilpatrick, J. Storr, and H. Seale, "Exploring the use of entertainment-education YouTube videos focused on infection prevention and control," AJIC Am. J. Infect. Control, vol. 46, no. 11, pp. 1218 1223,2018

[12] A. M. Marshall, “WhatsApp server-side media persistence,” Digit. Investig., 2018.

[13] S. Moghavvemi, A. Sulaiman, N. I. Jaafar, and N. Kasem, "Social media as a complementary learning tool for teaching and learning: The case of youtube," Int. J. Manag. Educ., vol. 16, no. 1, pp. 37-42, 2018.

[14]C. Shane-simpson, A. Manago, N. Gaggi, and K. Gillespie-lynch, "Why Do College Students Prefer Facebook, Twitter, or Instagram? Site Affordances, Tensions Between Privacy and Self-Expression, and Implications for Social Capital," Comput. Human Behav., vol. 86, pp. 276-288, 2018.

[15]V. Pornsakulvanich, "Excessive use of Facebook: The influence of self-monitoring and Facebook usage on social support," Kasetsart J. Soc. Sci., vol. 39, no. 1, pp. 116-121, 2018. 